EXPERIENCING DESIGN 



\title{
EXPERIENCING DESIGN
}

\author{
THE \\ INNOVATOR'S \\ JOURNEY
}

\section{JEANNE LIEDTKA, KAREN HOLD, and JESSICA ELDRIDGE}

\author{
$\$$ Columbia Business School




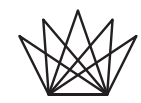

Columbia University Press

Publishers since 1893

New York Chichester, West Sussex

Copyright @ 2021 Jeanne Liedtka, Karen Hold, and Jessica Eldridge

All rights reserved

Library of Congress Cataloging-in-Publication Data

Names: Liedtka, Jeanne, author. | Hold, Karen, author. | Eldridge, Jessica, author.

Title: Experiencing design : the innovator's journey / Jeanne Liedtka, Karen Hold, Jessica Eldridge.

Description: New York : Columbia University Press, 2021. | Includes index.

Identifiers: LCCN 2020058119 (print) | LCCN 2020058120 (ebook)|

ISBN 9780231194266 (hardback) | ISBN 9780231550734 (ebook)

Subjects: LCSH: Technological innovations. | Design.

Classification: LCC HD45 .L476 2021 (print) | LCC HD45 (ebook) |

DDC 658.4/063-dc23

LC record available at https://lccn.loc.gov/2020058119

LC ebook record available at https://lccn.loc.gov/2020058120

Columbia University Press books are printed on permanent and durable acid-free paper. This book is printed on paper with recycled content.

Printed in the United States of America
$\begin{array}{lllllllllll}1 & 0 & 9 & 8 & 7 & 6 & 5 & 4 & 3 & 2 & 1\end{array}$

Book design by Leigh Ayers 
To all of our students

who inspire us as they work to make the world a better place 
